\title{
Seroprevalence and correlates of human T-cell lymphoma/leukemia virus type I antibodies among pregnant women at the University of Nigeria Teaching Hospital, Enugu, Nigeria
}

\author{
This article was published in the following Dove Press journal: \\ International Journal of Women's Health \\ 18 September 2014 \\ Number of times this article has been viewed
}

\author{
Augustine Ejike Okoye' \\ Obike Godswill Ibegbulam² \\ Robinson Chukwudi Onoh ${ }^{3}$ \\ Paul Olisaemeka Ezeonu ${ }^{3}$ \\ Ngozi I Ugwu' \\ Lucky Osaheni Lawani ${ }^{3}$ \\ Chukwudi Simon Anigbo ${ }^{2}$ \\ Charles E Nonyelu² \\ 'Department of Haematology \\ and Immunology, Federal Teaching \\ Hospital, Abakaliki, ${ }^{2}$ Department \\ of Haematology and Immunology, \\ University of Nigeria Teaching \\ Hospital (UNTH), Ituku-Ozalla, \\ ${ }^{3}$ Department of Obstetrics and \\ Gynaecology, Federal Teaching \\ Hospital, Abakaliki, Nigeria
}

Background: Human T-cell lymphoma/leukemia virus (HTLV)-1 is a retrovirus transmitted vertically from mother to child parenterally and sexually by infected lymphocytes.

Objective: The objective of this study was to determine the seroprevalence of HTLV-1 antibodies and associated risk factors for HTLV-1 infection among pregnant women in University of Nigeria Teaching Hospital, Enugu, southeast Nigeria.

Materials and methods: A cross-sectional study was carried out from July to October 2010. Two hundred pregnant women were recruited consecutively from the antenatal clinic. Five milliliters of blood was collected from each of the participants into a plain sterile bottle and allowed to clot. The serum obtained was stored at $-20^{\circ} \mathrm{C}$ until required for analysis. The serum samples were then analyzed for antibodies to HTLV-1 using a one-step incubation double-antigen sandwich enzyme-linked immunosorbent assay kit. Participants' demographic characteristics and degree of exposure to the risk factors associated with HTLV-1 infection were captured using a questionnaire. Statistical analysis of results was done using SPSS version 17.

Results: The average age of the pregnant women was 28.94 years (standard deviation 4.17). The age-group with the highest representation was those between the ages of 26 and 30 years. Thirty-six percent of the population was above 30 years old. The result of the tests showed that only one respondent, a 31-year-old pregnant woman tested positive for HTLV-1 antibodies. Therefore, the seroprevalence of HTLV-1 antibodies among pregnant women attending the antenatal clinic at University of Nigeria Teaching Hospital was $0.5 \%$, with a $95 \%$ confidence interval of $0 \%-2.8 \%$. Some of the sociodemographic risk factors of HTLV-1 infection found to be applicable to the 31-year-old woman who tested positive included positive history of previous sexually transmitted diseases, high parity, low socioeconomic status, female sex, and age above 30 years. The pregnant women that participated in this study were exposed to risk factors and behaviors associated with HTLV-1 infection. Some of the pregnant women $(17.5 \%)$ had contracted sexually transmitted diseases, and $80.5 \%$ did not use condoms during coitus

Conclusion: The seroprevalence obtained in this study was low, though it is $100 \%$ for anyone infected. More prospective and multicenter studies are required to determine the infectivity of HTLV-1 among pregnant women in Nigeria.

Keywords: human T-cell lymphoma/leukemia virus, HTLV-1 antibodies, pregnant women, seroprevalence
Correspondence: Robinson Chukwud Onoh

Department of Obstetrics and Gynaecology, Federal Teaching Hospital, PMB I02, Abakaliki,

Ebonyi 48000I, Nigeria

Tel +2348037007519

Email drrobonoh@gmail.com 


\section{Introduction}

Human T-cell lymphoma/leukemia virus (HTLV)-1 was identified in 1980 as the causative agent for adult T-cell leukemia. ${ }^{1,2}$ It was the first human retrovirus to be identified and is a member of the deltaretroviruses. ${ }^{1}$ Other deltaretroviruses include HTLV-2, simian T-cell leukemia virus, and bovine leukemia virus. ${ }^{1}$

HTLV-1 can infect T lymphocytes, B lymphocytes, monocytes, and fibroblasts. ${ }^{1,3}$ However, the provirus is mainly detected in CD4-positive lymphocytes, with about 10\% detected in CD8-positive T lymphocytes. ${ }^{1,4}$ The major clinical effect of this viral infection is neoplasia. It has now been proven to be the etiological agent for adult T-cell leukemia/ lymphoma (ATL), because virtually all cases of ATL are seropositive for HTLV-1 and the HTLV-1 provirus is also present in leukemic cells but not in other cells in these patients. ${ }^{5,6}$ It also causes HTLV-1 associated myelopathies, infective dermatitis, uveitis, arthropathy, interstitial pneumonitis, immune deficiency with opportunistic infection, cutaneous lymphomas such as mycosis fungoides, Sézary's syndrome, Sjögren's syndrome, renal failure, B-cell leukemia, and small-cell lung cancer.

HTLV-1 infects over 20 million people worldwide. ${ }^{6-8}$ However, the distribution is not uniform, and is characterized by clusters of high endemicity. ${ }^{9}$ A high seroprevalence rate of HTLV- 1 antibodies of more than $2 \%$ in adults has been found in southwestern Japan, the Caribbean Basin, South America, parts of the Middle East, Melanesia, the West Indies, Jamaica, and Central Africa. ${ }^{10-16}$ The prevalence rate in the African adult population is approximately $0.5 \%-33 \%$. ${ }^{7,9}$ Reported endemic areas include Gabon, Cameroon, Guinea, the Democratic Republic of Congo, and Ivory Coast. ${ }^{14,17}$ Several European studies have demonstrated that the seroprevalence of HTLV-1 infection in pregnant women is 50- to 100 -fold higher than that found in blood donors. ${ }^{10}$

Some sociodemographic factors associated with high prevalence of HTLV-1 infection include geographical location, lower socioeconomic status, female sex, higher age, marital status, promiscuity, and recurrent sexually transmitted diseases (STDs). ${ }^{7}$ In endemic areas, the prevalence in children is very low, but starts to increase during the teenage years. The age-related increase is more marked in females than males. ${ }^{7}$ At the age of 40-50 years, women are significantly more likely to be infected than men. ${ }^{7}$

The incubation period of HTLV-1 infection is prolonged (from 6 months to decades), but the onset of myelopathy is shorter in patients who acquired the infection through breastfeeding or by the vertical route. ${ }^{11-13}$ The time interval between blood transfusion and development of HTLV-1associated myelopathy is also short in immunocompromised individuals. ${ }^{11,12}$

The three main modes of transmission of HTLV-1 include mother-to-child (vertical) transmission, sexual transmission, and parenteral transmission. Transmission via mother to child varies from $10 \%$ to $20 \%{ }^{9,10}$ It occurs usually after the decline of protective maternal immunoglobulin (Ig)G antibodies, mainly via the ingestion of maternal lymphocytes containing the HTLV-1 provirus during breastfeeding. Transplacental transmission can occur, but is not as common. ${ }^{10}$ Several studies have shown that ATL in adults is very likely to result from early childhood infections. ${ }^{9,14,15}$ Sexual transmission can be from male to female in the majority of cases, male to male, and rarely from female to male. ${ }^{1,15}$ In a study conducted in Japan, the risk of transmission from an infected wife to her husband was less than $1 \% .^{7}$ Transmission from an infected husband to his wife over a 10 -year period was $61 \% .^{7}$ In parenteral transmission, blood transfusion is most efficient, since the infecting viral load in the blood is usually high. ${ }^{1,9,17}$ Overall, the transmission of HTLV-1 is similar to that of human immunodeficiency virus (HIV), although HIV is considerably more infectious, since cell-free HIV can transmit the viral infection, whereas cell-free HTLV-1 cannot. ${ }^{18,19}$

Pregnant women are sexually active, and are at a high risk of contracting, spreading, and maintaining HTLV-1 in a community. ${ }^{6}$ In Ghana, the prevalence of HTLV-1 antibodies among pregnant women was $2.1 \% .{ }^{20}$ Babies born to these HTLV-1-infected mothers will constitute part of the adult blood-donor pool of the future. They can serve as reservoirs for propagation of the virus infection. Studies in Japan have shown that more than $90 \%$ of HTLV-1-seropositive children have mothers who are seropositive. Forbi and Odetunde recorded a high seroprevalence of $16.7 \%$ in a study they conducted in southwestern Nigeria. ${ }^{6}$

Antenatal screening for HTLV-1 and recommendations of formula feeding have been practiced in Nagasaki, Japan since $1987,{ }^{21}$ and are being proposed in Europe ${ }^{21,22}$ and Jamaica. ${ }^{23}$ HTLV-1 is transmitted through body fluids (blood, semen, vaginal fluid, breast milk) from an infected person, like HIV, hepatitis $\mathrm{B}$ virus, and hepatitis $\mathrm{C}$ virus. ${ }^{24}$ The antibodies or antigens of the aforementioned viruses are currently routinely screened for during pregnancy in Nigeria. HTLV-1 infection has not been given adequate attention, despite the fact that Nigeria is located in tropical Africa, where HTLV-1 infection is purportedly endemic.

Pregnant women were chosen as the study group because they constitute a major source of contracting, spreading, 
and maintenance of HTLV-1 infection in the population, and prophylactic measures targeted at them will have a strategic impact on its spread. We therefore wished to determine the seroprevalence of anti-HTLV-1 antibodies among pregnant women and to identify the sociodemographic correlates of HTLV-1 infection, as well as to justify the need for routine anti-HTLV-1 antibody screening in antenatal care.

\section{Materials and methods}

A cross-sectional study was carried out among pregnant women attending an antenatal clinic at the University of Nigeria Teaching Hospital (UNTH), Ituku-Ozalla, Enugu State, southeast Nigeria. The pregnant women recruited from the antenatal clinic were at various stages of gestation. Sample collection was done between July and October 2010, and the minimum sample size required for this study was obtained using a sample size-determination formula, which gave a sample size of 32 using prevalence of HTLV-1 antibodies in pregnant women of $2.1 \%{ }^{20,25}$ Statistical credence was given to the study by increasing the sample size to 200 pregnant women. Informed consent was obtained from the study group, and the participants were enrolled consecutively. This study was approved by the joint University of Nigeria, Nsukka/ UNTH Research Ethics Committee. Demographic data were obtained from each participant using a questionnaire. Inclusion criteria were giving consent and accessing antenatal care at the UNTH antenatal clinic, as well as pregnant women 16 years and above.

Exclusion criteria included not giving informed consent and pregnant women with acute complications of pregnancy. Five milliliters of blood was collected from the antecubital fossa of each participant after cleaning with methylated spirits. The blood was transferred into a sterile plain bottle and allowed to clot. The serum was separated into another sterile plain bottle and stored immediately at $-20^{\circ} \mathrm{C}$ till the required sample size was obtained. The entire collected specimen was screened for anti-HTLV-1 antibodies using a commercially available enzyme-linked immunosorbent assay (ELISA) kit (HTLV 1 + 2 ELISA KIT, lot number 8196-12; Diagnostic Automation, Calabasas, California) based on onestep incubation and the double-antigen sandwich principle. Samples that tested positive for HTLV-1 antibodies were then subjected to Western blotting (WB) to confirm HTLV-1 infection.

The WB technique is one way of confirming a serum as positive for HTLV-1 antibodies, as well as separating HTLV-1 from HTLV-2 infections. This is imperative, because the ELISA kit used in this study incorporated both HTLV-1 and HTLV-2 antigens on the microwell. WB is able to detect antibodies against the complex mixture of antigens found in HTLV infection. It is a highly specific technique. There are criteria for confirmation of HTLV-1 infection by WB, but the US Public Health Service Working Group criteria for confirmation of seropositivity is the most popular. In view of the difficulty procuring the WB, the test was done in the UK by Dr Emmanuel Nna of Safety Biomedical, Innovation Center, Crainfield, University Teaching Park, Bedfordshire. The kit used for the confirmation of the positive sample in this study was purchased from Thermo Fisher Scientific, UK. Electroblotting was done with an Invitrogen-1 blot machine. A monoclonal antibody of an $\mathrm{IgG}_{1}$ isotype (MAB 811) specific for HTLV-1 core protein $\mathrm{P}_{19}$ was used to confirm that indeed the reactive sample was as a result of HTLV-1 infection.

Table I Age distribution of participants

\begin{tabular}{|c|c|c|}
\hline Variables & $\begin{array}{l}\text { Frequency } \\
n=200\end{array}$ & Percentage \\
\hline \multicolumn{3}{|l|}{ Age-group, years } \\
\hline $16-20$ & 14 & 7.0 \\
\hline $21-25$ & 29 & 14.5 \\
\hline $26-30$ & 85 & 42.5 \\
\hline $31-35$ & 60 & 30.0 \\
\hline $36-40$ & 12 & 6.0 \\
\hline $4 I-45$ & 0 & 0 \\
\hline $46-50$ & 0 & 0 \\
\hline $5 I-55$ & 0 & 0 \\
\hline \multicolumn{3}{|l|}{ Ethnic group } \\
\hline Ibo & 196 & 98 \\
\hline Yoruba & 1 & 0.5 \\
\hline Hausa & 1 & 0.5 \\
\hline Others & 2 & 1.0 \\
\hline \multicolumn{3}{|l|}{ Marital status } \\
\hline Married & 194 & 97 \\
\hline Single & 3 & 1.5 \\
\hline Divorced & 1 & 0.5 \\
\hline Separated & 0 & 0 \\
\hline Widowed & 2 & 1.0 \\
\hline \multicolumn{3}{|l|}{ Educational qualifications } \\
\hline No formal education & 3 & 2.5 \\
\hline Primary & 4 & 2.0 \\
\hline Secondary & 57 & 28.5 \\
\hline Postsecondary & 50 & 25.0 \\
\hline Postgraduate & 84 & 42.0 \\
\hline \multicolumn{3}{|l|}{ Accommodation } \\
\hline One room & 22 & 11.0 \\
\hline Two rooms & 61 & 30.5 \\
\hline Flat & 95 & 47.5 \\
\hline House & 22 & 11.0 \\
\hline \multicolumn{3}{|l|}{ Occupation } \\
\hline Student & 46 & 23 \\
\hline Unemployed & 38 & 19 \\
\hline Civil servant & 62 & 31 \\
\hline Trader & 31 & 15.5 \\
\hline Others & 23 & 11.5 \\
\hline
\end{tabular}


The data collected were subjected to descriptive analysis. This involved the generation of frequency-distribution data for the different variable responses. These generated data are presented in the tables. Data were analyzed using SPSS version 17.

\section{Results}

A total of 200 blood samples were screened for anti-HTLV-1 antibodies. The pregnant women were mainly within the age range $21-35$ years (174 [97\%]), and 72 (36\%) were above 30 years. The mean age of the pregnant women was $28.9 \pm 4.17$ years. Most of the women 196 (98\%) were Ibos. A majority of the pregnant women were married (194 [97\%]), had secondary education or more (191 [95.5\%]), lived in flats or owned their houses (117 [58.5\%]), and were gainfully employed (116 [58\%]) (Table 1).

Table 2 shows the history of blood donation and transfusion. A majority of the participants $186(93 \%)$ had not donated blood in the past, and 192 (96\%) had not received blood transfusion. About $87.5 \%$ of the participants had not injected themselves or shared instruments, and $80.5 \%$ did not use condoms (Table 3).

A majority of the women (162 [81\%]) had not been diagnosed or treated for STDs. Ninety-six percent of the pregnant women had one sex partner. The other sex-related risk behaviors associated with transmission of HTLV-1 are represented in Table 4 . The only person that tested positive for HTLV-1 infection was a 31-year-old married pregnant housewife with secondary education, a history of two previous STDs, and who lived in a two-room apartment with three children and her husband. This resulted in a seroprevalence of $0.5 \%$, with a $95 \%$ confidence interval of $0 \%-2.8 \%$.

Table 2 Frequency of blood donation and transfusion - history

\begin{tabular}{lll}
\hline Characteristics & $\begin{array}{l}\text { Frequency } \\
\mathbf{n}=\mathbf{2 0 0}\end{array}$ & Percentage \\
\hline $\begin{array}{l}\text { Donated blood in the past } \\
\text { Yes }\end{array}$ & 14 & 7.0 \\
No & 186 & 93 \\
Number of times & & \\
0 & 186 & 93 \\
I-5 & 14 & 7.0 \\
$6-10$ & 0 & 0 \\
II-I5 & 0 & 0 \\
I6-20 & 0 & 0 \\
2 I-25 & 0 & 0 \\
Received blood in the past & & \\
Yes & 8 & 4.0 \\
No & 192 & 96.0 \\
No response & 0 & 0 \\
\hline
\end{tabular}

Table 3 History of intravenous drug use and use of condoms

\begin{tabular}{|c|c|c|}
\hline Variables & $\begin{array}{l}\text { Frequency } \\
n=200\end{array}$ & Percentage \\
\hline \multicolumn{3}{|c|}{ Injected drugs or shared instruments } \\
\hline Yes & 25 & 12.5 \\
\hline No & 175 & 87.5 \\
\hline \multicolumn{3}{|c|}{ Use condoms when having sex } \\
\hline Yes & 37 & 18.5 \\
\hline No & 161 & 80.5 \\
\hline No response & 2 & 1.0 \\
\hline
\end{tabular}

\section{Discussion}

Pregnant women are sources of dissemination of HTLV-1 infection. A pregnant woman can transmit the virus vertically to her child or sexually to her husband. Preventive measures targeted at them, especially in countries with high prevalence, will have a significant impact on the reduction of the spread of this deadly blood-borne virus.

The medical consequences of HTLV-1 infection are grave. It has been implicated as a causative agent of some hematological malignancies like ATL, neurological diseases like toxic shock syndrome or HTLV-1 associated myelopathy, and some chronic inflammatory conditions (uveitis, arthropathies, and myositis). ${ }^{11}$ The chronicity of HTLV-1 infection, difficulty encountered in its diagnosis, and lack of definitive treatment options have made preventive interventions like screening studies imperative. Knowledge of a person's anti-HTLV-1 antibody status will help prevent the spread of the infection, since infected mothers will be advised not to breastfeed their infants.

Table 4 History of sexual practices and sexually transmitted diseases

\begin{tabular}{|c|c|c|}
\hline Variables & $\begin{array}{l}\text { Frequency } \\
n=200\end{array}$ & Percentage \\
\hline \multicolumn{3}{|c|}{ Diagnosed with STD before } \\
\hline Yes & 35 & 17.5 \\
\hline No & 162 & 81 \\
\hline No response & 3 & 1.5 \\
\hline \multicolumn{3}{|c|}{ Had unprotected sex with } \\
\hline \multicolumn{3}{|c|}{ someone at risk of STD } \\
\hline Yes & 46 & 23 \\
\hline No & 144 & 72 \\
\hline No response & 10 & 5 \\
\hline \multicolumn{3}{|c|}{ If yes, was it partner who } \\
\hline \multicolumn{3}{|c|}{ abused hard drugs? } \\
\hline Yes & I & 0.5 \\
\hline No & 189 & 94 \\
\hline No response & 10 & 5 \\
\hline \multicolumn{3}{|c|}{ Partner diagnosed/treated for STD } \\
\hline Yes & 29 & 14.5 \\
\hline No & 161 & 80.5 \\
\hline No response & 10 & 5.0 \\
\hline
\end{tabular}

Abbreviation: STD, sexually transmitted disease. 
In Nigeria, little or no attention has been paid to this viral infection, and studies on HTLV-1 infection and its seroprevalence are few. Available studies were done in Ibadan, Zaria, and Calabar more than about half a decade ago. ${ }^{5,6}$ This study appears to be the first of its kind in southeastern Nigeria. The seroprevalence of HTLV-1 infection among pregnant women that participated in this study was $0.5 \%$. This value is lower than previous Nigerian reports. ${ }^{26}$

Among the 200 pregnant women screened, one of them tested positive to HTLV-1 infection (seroprevalence of $0.5 \%$ ). Though very few studies had been done in Nigeria, Forbi and Odetunde recorded a high prevalence of $16.7 \%$ out of the 120 pregnant women they studied. ${ }^{6}$ This is at variance with the $0.5 \%$ obtained in this study. This difference could be because the ELISA they used was less specific than the technique applied in this study, and they did not separate HTLV-1 from HTLV-2 infection via WB or polymerase chain reaction. In contrast, Armah et $\mathrm{al}^{20}$ in Ghana reported a prevalence of $2 \%$ out of 1,000 pregnant women they studied. In view of the inconsistent prevalence rates from the few available studies, it is therefore imperative that comprehensive multicenter studies should be carried out among pregnant women in Nigeria to establish the true prevalence of HTLV-1 infection among this group. Low seroprevalence rates have been recorded in Europe and America. The $0.5 \%$ obtained in this study could be said to be high, but may not be enough justification for routine screening of pregnant women for HTLV-1 during antenatal care, as further studies on the cost implications will be desired.

Though some studies have shown that HTLV-1 infection is endemic in Africa, ${ }^{7,10}$ low prevalence rates have been recorded among the general population in various African countries. For instance, South Africa has a prevalence of $0 \%,{ }^{27,28}$ Zimbabwe $0.11 \%,{ }^{29}$ Senegal $1.2 \%,{ }^{30}$ Namibia $1 \%,{ }^{31}$ Mozambique $0.7 \%,{ }^{20,32}$ and Congo $0.7 \% .^{20,33}$ In Europe, it ranges from $0 \%$ to $0.02 \%{ }^{7,10}$ In addition, genomic sequencing of HTLV-1 suggests that the virus originated from the IndoMalay region and eventually spread to Africa, Japan, and Europe. ${ }^{34}$ This may help justify the view that indeed HTLV-1 infection is not endemic in many African countries.

It is also known that high prevalence of HTLV-1 infection has a direct influence on the incidence of ATL. For instance, in Japan, with a prevalence of 3\%, ATL accounts for $43 \%$ of all cases of non-Hodgkin's lymphoma. ${ }^{34}$ On the island of Kyushu in Japan, the prevalence is $15 \%$, and ATL accounts for $75 \%$ of non-Hodgkin's lymphoma. ${ }^{34}$ Despite the claim that HTLV-1 infection is endemic in Africa, there is little or no evidence to prove an increasing incidence of ATL in
Nigeria. However, one cannot rule out underdiagnosis as a result of inadequate diagnostic tools and poor awareness.

Previous investigators have found that certain sociodemographic factors influence the seroprevalence of HTLV-1 infection. These factors include increasing age, sex, geographical location, marital status, poor socioeconomic status, recurrent STDs, and female sex. ${ }^{7}$ However, the low seroprevalence rates of $0.5 \%$ obtained among pregnant women is not high enough to justify a statistical correlation between these risk factors and their effect on HTLV-1 infection. Such a correlation may be possible if the sample size is increased.

Finally, this study recorded a low seroprevalence of HTLV-1 infection, but multicenter and large prospective studies are needed to conclusively establish the true seroprevalence of HTLV-1 among pregnant women in Nigeria.

\section{Recommendations}

From the findings of this study, routine screening of pregnant women attending an antenatal clinic in UNTH Enugu cannot be recommended until a cost-effective study of such screening is carried out.

Prospective and multicenter research on the seroprevalence of HTLV-1 infection among pregnant women should be encouraged to help justify the need for routine antenatal screening for HTLV-1 infection. A standard and simultaneous national epidemiological survey should be carried out in all the geopolitical zones of Nigeria to establish the true seroprevalence of HTLV-1 infection and its pattern of distribution. The reference data obtained should be periodically reviewed and updated. A national research center should be set up and adequately funded to coordinate and possibly subsidize the cost of important capital-intensive researches. It also should facilitate payments and procurement of materials and kits required for such research.

\section{Limitations}

The ELISA kit for HTLV-1 antibodies screening was not available in the market. The kit that was readily available incorporated antigens for both HTLV-1 and -2, such that to confirm that the positive results were indeed as a result of HTLV-1 infection and not HTLV-2, we needed a confirmatory test (WB). The cost and logistics of procuring the Western blot kit were so enormous that the reactive sample, which was split into two and four nonreactive samples, were sent to the UK for WB assay. Lipemic or hemolyzed samples might have interfered with the results, and hence efforts were made to eliminate such samples. The very low prevalence of HTLV-1 infection in the study population makes it difficult to 
statistically analyze its relationship with sociodemographic characteristics and risky behavior of the participants.

\section{Acknowledgment}

We wish to acknowledge the management of UNTH Enugu for providing the enabling environment for this study, and our gratitude goes to the departmental consultants and resident doctors who supported us in the course of this research. We are also grateful to Dr Emmanuel Nna of Safety Biomedical Ltd, Innovation Center, Crainfield, University Teaching Park, Bedfordshire, UK.

\section{Disclosure}

The authors report no conflicts of interest in this study.

\section{References}

1. Matsuoka M. Human T-cell leukemia virus type-1 (HTLV-1) infection and the onset of adult T-cell leukemia (ATL). Retrovirology. 2005;2:27.

2. Poiesz BJ, Ruscetti FW, Gazdar AF, Bunn PA, Minna JD, Gallo RC. Detection and isolation of type $\mathrm{C}$ retrovirus particles from fresh and cultured lymphocytes of a patient with cutaneous T-cell lymphoma. Proc Natl Acad Sci U S A. 1980;77:7415-7419.

3. Koyanagi $\mathrm{Y}$, Itoyama $\mathrm{Y}$, Nakamura $\mathrm{N}$, et al. In vivo infection of human T-cell leukemia virus type 1 in non-T cells. Virology. 1993;196: $25-33$.

4. Yasunaga J, Sakai T, Nosaka K, et al. Impaired production of naive $\mathrm{T}$ lymphocytes in human T-cell leukemia virus type- 1 infected individuals: its implications in the immunodeficient state. Blood. 2001;97:3177-3183.

5. Analo HI, Akanmu AS, Akinsete I, Njoku OS, Okany CC. Seroprevalence of HTLV-1 and HIV infection in blood donors and patients with lymphoid malignancies. Cent Afri J Med. 1998;44:130-134.

6. Forbi JC, Odetunde AB. Human T-cell lymphotropic virus in a population of pregnant women and commercial sex workers in South Western Nigeria. Afr Health Sci. 2007;7:129-132.

7. Feigin RD, Cherry J, Demmler G, Kaplan s. Textbook of Pediatric Infectious Diseases. 5th ed. Philadelphia: Saunders; 2003.

8. Seiki M, Hattori S, Hirayama Y, Yoshida M. Human adult T-cell leukemia virus: complete nucleotide sequence of the provirus genome integrated in leukemia cell DNA. Proc Natl Acad Sci U S A. 1983;80: 3618-3622.

9. Plancouline S, Gessain A, Tortevoye P, et al. A major susceptibility locus for HTLV-1 infection in childhood maps to chromosome 6q27. Hum Mol Genet. 2006;15:3306-3312.

10. Machuca A, Tuset C, Soriano V, Caballero E, Aguilera A, Ortiz de Lejarazu R. Prevalence of HTLV infection in pregnant women in Spain. Sex Transm Infect. 2000;76:366-370.

11. Höllsberg P, Hafler AD. Seminars in medicine of the Beth Israel Hospital, Boston. Pathogenesis of diseases induced by human lymphotropic virus type I infection. N Engl J Med. 1993;328:1173-1182.

12. Osame M, Izumo S, Igata A, et al. Blood transfusion and HTLV-I associated myelopathy. Lancet. 1986;2:104-105.

13. Gout O, Baulac M, Gessain A, et al. Rapid development of myelopathy after HTLV-I infection acquired by transfusion during cardiac transplantation. N Engl J Med. 1990;322:383-388.

14. Murphy EL, Hanchard B, Figueroa JP, et al. Modelling the risk of adult T-cell leukemia/lymphoma in persons infected with human T-cell lymphotropic virus type I. Int J Cancer. 1989;43:250-253.
15. Bartholomew C, Jack N, Edwards T, et al. HTLV-I serostatus of mothers of patients with adult T-cell leukaemia and HTLV-I-associated myelopathy/tropical spastic paralysis. J Hum Virol. 1998;1:302-305.

16. Kaplan JE, Khabbaz RF, Murphy EL, et al. Male-to-female transmission of human T-cell lymphotropic virus types I and II: association with viral load. The Retrovirus Epidemiology Donor Group. J Acquir Immune Defic Syndr Hum Retrovirol. 1996;12:193-201.

17. Okochi K, Sato H, Hinuma Y. A retrospective study on transmission of adult $\mathrm{T}$ cell leukemia virus by blood transmission: seroconversion in recipients. Vox Sang. 1984;46:245-253.

18. Williams AE, Fang CT, Slamon DJ, et al. Seroprevalence and epidemiological correlates of HTLV-I infection in US blood donors. Science. 1988;240:643-646.

19. Bartholomew C, Saxinger WC, Clark WN, et al. Transmission of HTLV-I and HIV among homosexual men in Trinidad. JAMA. 1987;257: 2604-2608

20. Armah HB, Narter-Olaga EG, Adjei AA, Asomaning K, Gyasi RK, Tettey Y. Seroprevalence of human T-cell lymphotropic virus type I among pregnant women in Accra, Ghana. J Med Microbiol. 2006;55: 765-770.

21. Wiktor SZ, Pate EJ, Rosenberg PS, et al. Mother-to-child transmission of human T-cell lymphotropic virus type I associated with prolonged breast feeding. J Hum Virol. 1997;1:37-44.

22. Nightingale S, Orton D, Ratcliffe D, Skidmore S, Tosseill J, Desselberger U. Antenatal survey for the seroprevalence of HTLV-1 infections in the West Midlands, England. Epidemiol Infect. 1993; 110:379-387.

23. Otigah C, Kelly A, Aitken C, Norman J, Jeffries D, Erskine DJ. Is HTLV-1 status another antenatal screening test that we need? $\mathrm{Br} J$ Obstet Gynaecol. 1997;104:258-260.

24. Lal RB. Delineation of immunodominant epitopes of human T-lymphotropic virus types I and II and their usefulness in developing serologic assays for detection of antibodies to HTLV-I and HTLV-II. J Acquir Immune Defic Syndr Hum Retrovirol. 1996;13 Suppl 1: S170-S178.

25. Israel GD. Determining sample size. 1992. Available from: https://edis. ifas.ufl.edu/pdoo6. Accessed July 30, 2014.

26. Fleming AF, Maharajan R, Abraham M, et al. Antibodies to HTLV-I in Nigerian blood-donors, their relatives and patients with leukaemias, lymphomas and other diseases. Int J Cancer. 1986;38:809-813.

27. Hale A, Leung T, Sivasubramaniam S, Kenny J, Sutherland S. Prevalence of antibodies to HTLV in antenatal clinic attendees in south east London. J Med Virol. 1997;52:326-329.

28. Houston S, Thornton C, Emmanuel J, Latif AS. Human T-cell lymphotropic virus type-1 in Zimbabwe. Trans R Soc Trop Med Hyg. 1994;88:170-172.

29. Steele AD, Bos P, Joubert JJ, et al. Low prevalence of human T lymphotropic virus type I in !Kung San in Bushmanland, Namibia. Am J Trop Med Hyg. 1994;51:460-465.

30. Hunsmann G, Bayer H, Schneider J, et al. Antibodies to ATLV/HTLV-1 in Africa. Med Microbiol Immunol. 1984;173:167-170.

31. Sherman MP, Saksena NK, Dube DK, Yanagihara R, Poiesz BJ. Evolutionary insights on the origin of human T-cell lymphoma/leukemia virus type I (HTLV-I) derived from sequence analysis of a new HTLV-I variant from Papua New Guinea. J Virol. 1992;66:2556-2563.

32. Melo J, Beby-Defaux A, Faria C, et al. HIV and HTLV prevalences among women seen for sexually transmitted diseases or pregnancy follow-up in Maputo, Mozambique. J Acquir Immune Defic Syndr. 2000;23:203-204.

33. Tuppin P, Makuwa M, Guema T, Bazabana MM. Low HTLV-I/II seroprevalence in pregnant women in Congo and a geographic cluster of an HTLV-like indeterminate Western blot pattern. J Acquir Immune Defic Syndr Hum Retrovirol. 1996;11:105-107.

34. Shimoyama M. Peripheral T-cell lymphoma in Japan: recent progress. Ann Oncol. 1991;2 Suppl 2:157-162. 
International Journal of Women's Health

Dovepress

\section{Publish your work in this journal}

The International Journal of Women's Health is an international, peerreviewed open-access journal publishing original research, reports, editorials, reviews and commentaries on all aspects of women's healthcare including gynecology, obstetrics, and breast cancer. The manuscript management system is completely online and includes Visit http://www.dovepress.com/testimonials.php to read real quotes from published authors.

Submit your manuscript here: http://www.dovepress.com/international-journal-of-womens-health-journal 